\title{
Cell-based cardiovascular repair and regeneration in acute myocardial infarction and chronic ischemic cardiomyopathy - current status and future developments
}

\author{
CHRISTIAN TEMPLIN*, THOMAS F. LÜSCHER and ULF LANDMESSER* \\ Department of Cardiology, Cardiovascular Center, Cardiology, University Hospital Zurich \\ and Cardiovascular Research, Institute of Physiology, University Zurich, Switzerland
}

\begin{abstract}
Ischemic heart disease is the main cause of death and morbidity in most industrialized countries. Stem- and progenitor cell-based treatment approaches for ischemic heart disease are therefore an important frontier in cardiovascular and regenerative medicine. Experimental studies have shown that bone-marrow-derived stem cells and endothelial progenitor cells can improve cardiac function after myocardial infarction, clinical phase I and II studies were rapidly initiated to translate this concept into the clinical setting. However, as of now the effects of stem/ progenitor cell administration on cardiac function in the clinical setting have not met expectations. Thus, a better understanding of causes of the current limitations of cell-based therapies is urgently required. Importantly, the number and function of endothelial progenitor cells is reduced in patients with cardiovascular risk factors and/or coronary artery disease. These observations may provide opportunities for an optimization of cell-based treatment approaches. This review provides a summary of current evidence for the role and potential of stem and progenitor cells in the pathophysiology and treatment of ischemic heart disease, including the properties, and repair and regenerative capacities of various stem and progenitor cell populations. In addition, we describe modes of stem/progenitor cell delivery, modulation of their homing as well as potential approaches to "prime" stem/progenitor cells for cardiovascular cell-based therapies.
\end{abstract}

KEY WORDS: stem and progenitor cell, myocardial regeneration, myocardial infarction

\section{Introduction}

Coronary artery disease, i.e. acute myocardial infarction and ischemic cardiomyopathy, are the main causes of death in most of the developed countries and are a major socioeconomic healthcare problem (Landmesser et al. 2005). Despite improved pharmacological therapy and coronary revascularization procedures by either percutaneous coronary intervention $\mathrm{PCl}$ or coronary artery bypass surgery CABG there is still a major need for novel therapeutic approaches (Landmesser et al. 2005); (Ford et al. 2007). Whereas current treatment strategies aim largely to limit or delay progression of cardiac dysfunction (Landmesser et al. 2005; Landmesser et al. 2009; Segers et al. 2008) stimulation of vascular and cardiac repair mechanisms, such as those mediated by stem/progenitor cells, has become an important focus of cardiovascular research (Landmesser 2009). In fact, in patients with ischemic heart failure it is unlikely that the inhibition of novel neurohormonones other than catecholamines, angiotensin and aldosterone will further improve cardiovascular outcome, underlining the need for novel therapeutic concepts to promote cardiac repair (Landmesser et al. 2009).

Experimental and first small- to intermediate scale clinical studies have suggested the feasibility and safety of cell-based therapies in patients with ischemic cardiomyopathy (Landmesser 2009; Schachinger et al. 2006; Segers et al. 2008). Heterogeneous cell populations have been thoroughly investigated as potential sources of cardiac progenitors in cell based therapy for

Abbreviations used in this paper: CSC, cardiac stem cell; EPC, endothelial progenitor cell; ESC, embryonic stem cell; HSC, hematopoietic stem cell; iPS, induced pluripotent stem cell; MSC, mesenchymal stem cell; PCI, percutaneous coronary intervention.

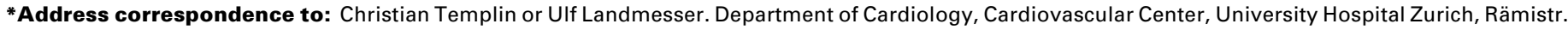
100, CH-8091 Zürich. Fax: +41 (0)44-255-4401. e-mail: Christian.Templin@usz.ch or Ulf.Landmesser@usz.ch
} 
ischemic heart disease. To date, different autologous adult stem and progenitor cells, in particular several subtypes of bone marrow-derived cells, isolated adipose tissue-derived or cardiacderived stem/progenitor cells are under preclinical and clinical evaluation. Additionally, embryonic stem cells and induced pluripotent stem cells provide regenerative capacity and improve cardiac function after ischemia in animal models (Nelson et al. 2009; van Laake et al. 2008). In an attempt to update the current field of cell-based therapy for ischemic heart disease, this review will give an overview on: (1) stem and progenitor cell populations in myocardial regenerative medicine, (2) routes of cell delivery, (3) current status of clinical trials, (4) mechanisms of adult stem and progenitor cell therapy, (5) limitations of current treatment strategies and (6) future developments of cell-based therapy.

\section{Overview of cell types for cardiac repair}

Over the past decade, early small and intermediate sized clinical trials have examined the effects of skeletal myoblasts (Menasche 2008; Menasche et al. 2003), circulating endothelial progenitor cells (Assmus et al. 2002; Hirsch et al. 2006), and bone marrow- derived mononuclear cell populations (Schachinger et al. 2006; Wollert et al. 2004) for treatment of ischemic heart disease. In addition, several progenitor and stem cell types have been studied in animal models to examine their potential use, including embryonic stem cells (ESCs) (Laflamme et al. 2007; van Laake et al. 2008), hematopoietic stem cells (HSCs) (Murry et al. 2004; Templin et al. 2008), mesenchymal stem cells (MSCs) (Mangi et al. 2003), endothelial progenitor cells (EPCs) (Aicher et al. 2003; Giannotti et al. 2010; Sorrentino et al. 2007), and resident cardiac stem cells (CSCs) (Beltrami et al. 2003; Laugwitz et al. 2005; Oh et al. 2003). Each cell types comprise unique profiles regarding isolation and culture, cell surface marker expression, transcription factors, expressed proteins, and ability to differentiate into different cell types:

\section{Adult stem and progenitor cells}

Bone-marrow-derived and circulating adult stem/progenitor cells: Stem/progenitor cells isolated from the bone marrow, peripheral blood, and other tissues have been used in cell-based treatments for ischemic heart disease. In contrast to pluripotent embryonic stem cells, adult stem cells present a limited and still controversial transdifferentiation capacity towards cardiomyocytes. The two major subsets of bone marrow-derived stem cells are HSCs and MSCs. The true bone-marrow stem cells comprise $<0.01 \%$ of the total bone marrow cells (Abkowitz et al. 2002; Pittenger et al. 2004) and may be isolated by direct marrow aspiration or obtained from peripheral blood after cytokine mobilization. Compared with other stem cell types, these cells appear to be present in greater numbers in vivo and have been studied particularly well, at least in part due to the fact that they can be rather easily obtained. Other multipotent progenitor cells located in the bone marrow include side-population cells, which are characterised by their ability to efflux Hoechst dye (Challen et al. 2006).

Hematopoietic stem/progenitor cells express CD34 and CD133 cell surface antigens and have shown the ability to home to injured myocardium, but whether they differentiate into cardiomyocytes has been debated (Jackson et al. 2001; Murry et al. 2004).

Mesenchymal stem cells can be identified in adult tissues including the bone marrow and adipose tissue (Tomita et al. 1999). Criterions for their characterization have recently been summarized by a position statement of the international society for cellular therapy and include the expression of CD105, CD73 and CD90 and lack of expression of markers such as CD34, CD45, CD14 or CD11b, CD79alpha or CD19 and HLA-DR surface molecules and their ability to differentiate into osteoblasts, adipocytes, and chondroblasts in vitro (Conget et al. 1999) (Dominici et al. 2006). MSCs can be isolated and expanded easily and have been suggested to improve left ventricular function after myocardial infarction (Makino et al. 1999; Schuleri et al. 2008; Toma et al. 2002) (Mangi et al. 2003). Furthermore, non-invasive multimodality imaging has suggested that therapy after myocardial infarction with allogeneic MSCs promotes active cardiac repair in vivo (Amado et al. 2006).

It has been proposed by experimental in vitro data that adipose tissue-derived MSCs may transdifferentiate into cardiomyocytelike cells and endothelial cells (Planat-Benard et al. 2004; PlanatBenard et al. 2004). However, as discussed above, there is no definite proof as of today for a complete transdifferentation into cardiomyocytes. Adipose cells have been regarded as an attractive source because they are available in high quantities and easy to obtain.

Endothelial progenitor cells comprise a heterogenous circulating cell population likely derived largely from the bone marrow (Urbich et al. 2004). Different types of endothelial progenitor cells have been proposed, in particular "early" and "late" EPCs, based on their appearance in the culture of circulating mononuclear cells in endothelial medium (Hur et al. 2004). Early EPCs promote likely endothelial repair (Giannotti et al. 2010) and angiogenesis (Sieveking et al. 2008) largely by paracrine effects, whereas late EPCs, that are very low in number, may become endothelial cells. The differentiation potential of early EPCs into cardiomyocytes has been questioned (Gruh et al. 2006).

Endothelial progenitor cells isolated from patients with diabetes or hypertension display a reduced activity in promoting reendothelialization of denuded arteries and blood flow recovery after ischemia when transplanted into nude mice (Giannotti et al. 2010; Landmesser et al. 2004; Sorrentino et al. 2007), pointing to an important limitation of current cell-based treatment approaches in these patients. The functional deficits that cause these reduced in vivo activities remain to be further characterized, but likely include reduced nitric oxide availability and an accelerated senescence (Giannotti et al. 2010; Sorrentino et al. 2007). Notably, assays of a reduced functionality of bone-marrow-derived mononuclear cells, such as impaired migration or diminished colony formation capacity in vitro, have been associated with a decreased functional benefit in cell therapy trials (Assmus et al. 2007).

Fetal and umbilical cord blood cells may possess greater plasticity than adult progenitor cells due to their prenatal origin. Umbilical cord blood contains a number of progenitor cell populations, including HSCs, MSCs, and unrestricted somatic stem cells, however, evidence of pluripotency after in vitro expansion is still lacking. Animal studies have shown an improvement in left ventricular function (Iwasaki et al. 2009; Kim et al. 2005).

Resident cardiac stem and progenitor cells are a relatively rare cell population in the heart, which have been classified according to surface marker or transcription factor expression (Beltrami et 
al. 2003; Hierlihy et al. 2002; Oh et al. 2003). C-Kit ${ }^{+}$cells have the capacity for self-renewal, clonogenicity, and pluripotency through differentiation into myogenic, endothelial, and smooth muscle lineages in vitro and may contribute to repair of ischemic myocardium (Beltrami et al. 2003). A further population of cardiac stem cells that express stem cell antigen-1 (Sca-1) have been differentiated into cells expressing cardiac specific markers in vitro (Oh et al. 2003). Furthermore, it has been demonstrated that Isl $1^{+}$cells can be differentiated into a cardiac phenotype with electrophysiological properties of mature cardiomyocytes (Laugwitz et al. 2005). Cardiospheres, which are spherical clusters of cells, are plated and grown in culture to yield cardiosphere-derived cells in addition to other populations of resident cardiac progenitors (Smith et al. 2008). Recently, Messina et al. demonstrated that cardiospheres could be isolated, and expanded to provide a potentially useful population of autologous cardiac stem cells (Messina et al. 2004). Several experimental studies using different preparations of cardiac-derived stem/progenitor cells have demonstrated positive effects on left ventricular function, remodeling, and infarct size; however, this has not been observed in all studies (Beltrami et al. 2003; Li et al. 2009; Oh et al. 2003). In particular, no long-term engraftment and benefit has been observed after transplantation of Sca-1-positive cardiac derived stem/progenitor cells.

Skeletal myoblasts transplantation into the heart as a cellbased strategy improved left ventricular function and reduced cardiac remodelling either to mechanical or scaffolding effects (Menasche 2008; Menasche et al. 2003). Unfortunatly, skeletal myoblasts do not transdifferentiate into cardiomyocytes (Menasche 2008). Remarkably, these cells lack electrical integrity and can therefore induce arrhythmias (Menasche et al. 2008). Moreover these cells fail to show long term beneficial effects on LV-function (Menasche et al. 2008). A small randomized controlled trial found that application through a 3-dimensional guided catheter system was favourable in terms of left ventricular function, quality of life and symptoms relief (Dib et al. 2009). However, the first randomized placebo-controlled study of myoblast transplantation (MAGIC trial) failed to improve cardiac function as assessed by echocardiography (Menasche et al. 2008).

Embryonic stem cells are undifferentiated, pluripotent cells obtained from the inner cell mass of blastocysts that have the most promising potential for organ regeneration (Segers et al. 2008; Smith 2001). Their unlimited capacity for differentiation has gained incremental interest for their use in regenerative cardiology. Previous studies of ischemia and reperfusion showed improved cardiac function, directly related to paracrine effects, after transplantation of undifferentiated murine ESCs (Crisostomo et al. 2008; Min et al. 2003). Of note, transplantation of undifferentiated murine ESCs can result in teratoma formation (Nussbaum et al. 2007). The risk can be reduced by transplanting predifferentiated ESC-derived cardiomyocytes. In post-infarcted rat hearts, such cells ameliorate cardiac function and blunt left ventricular remodeling without teratoma formation (Caspi et al. 2007; Laflamme et al. 2007). Nevertheless, further investigations of tumor formation, immunologic responses and regenerative capacity are required to delineate the therapeutic potential of differentiated ESC. The isolation methods by which ESCs can be obtained have raised many ethical issues. This may form an obstacle for further discovery process both in preclinical and clinical setting (Murry et al. 2008; Passier et al. 2008).

Induced pluripotent stem cells (iPSCs) can be generated by retroviral transduction of so-called 'stemness' transcription factors (Geoghegan et al. 2008; Takahashi et al. 2007; Yu et al. 2007). Such cells can be maintained in culture for several months and induced to differentiate into lineages of all three germ layers, including cardiomyocytes, with electrophysiological properties and a gene expression profile that is similar to ESC-derived cardiomyocytes (Mauritz et al. 2008; Nelson et al. 2009). To reduce the risk of insertional mutagenesis following infection with retroviral vectors, the technique has recently been refined to incorporate virus-free approaches for gene delivery (Okita et al. 2008). Furthermore, a recent study was able to generate humaninduced pluripotent stem cells by direct delivery of reprogramming proteins without DNA vectors (Kim et al. 2009). Also, the generation of functional cardiomyocytes from human induced pluripotent stem cells has been reported (Zhang et al. 2009). The strategy of reprogramming somatic cells could be also used to develop patient-specific stem cells, which could be a unique resource in studying genetic mechanisms of disease development, drug actions, and regenerative biology.

\section{Routes of cell delivery}

To date several routes of cell delivery are employed, including (1) intravenous (Barbash et al. 2003); (2) intracoronary (Strauer et al. 2002), (3) direct transepicardial (intramyocardial)"(Perin et al. 2006) or catheter-based transendocardial (intramyocardial) injection using electromechanical voltage mapping (Sherman et al. 2006), and (4) a recently established approach of transvenous injection into coronary veins (Thompson et al. 2003). Each delivery technique has its own risks and benefits, and their suitability may also depend on the cell type used.

(1) The least invasive technique is systemic intravenous infusion, which involves injecting progenitor cell suspensions into a vein followed by homing of the cells to the injured myocardium (Price et al. 2006). The primary disadvantage of this approach is that cells may be trapped in the pulmonary circulation before they reach the systemic circulation (Barbash et al. 2003; Templin et al. 2006).

(2) Percutaneous coronary cell delivery demonstrates the most frequent application route in the clinical setting. Under these conditions, cells are injected via an over-the wire balloon catheter into the vessel supplying the ischemic territory. The balloon is intermittently inflated to transiently stop coronary flow and allow cell distribution. Interestingly, a recent study in the porcine myocardial infarction model has suggested that prolonged balloon inflation is not necessary for the intracoronary approach using mononuclear bone-marrow-derived cells (Tossios et al. 2008). Notably, for intracoronary injection of mesenchymal stem cells in a dog model, however, induction of microinfarctions has been described (Vulliet et al. 2004). In some studies it was observed that the percutaneous intracoronary approach showed an increased engraftment of transplanted MSCs in pigs after myocardial infarction as compared to intramyocardial injection or intravenously transplanted cells (Freyman et al. 2006) (Moscoso et al. 2009). However, a recent study using bone marrow-derived mononuclear cells showed a 7-fold greater number of cells in the myocardium for the intramyocardial method and a 10-fold greater 
number of cells in the lungs in the intracoronary group of pigs (Makela et al. 2009). The opposing results may be related to different cell populations. In any case, the intracoronary approach requires transmigration of the endothelial barrier, whereas after intramyocardial injection the cells are largely primarily in the interstial space.

(3) Direct intramyocardial injections can be applied through the epicardium into the underlying ischemic myocardium during cardiac surgery when the heart is fully exposed. An advantage of this approach is the ability to target specific areas of myocardium and scar under direct visualization. In contrast, the benefit of direct intramyocardial injection may be limited by poor cell diffusion (Melo et al. 2004) and applications for larger areas require multiple injections.

Percutaneous transendocardial delivery is performed through direct injection of cells into the myocardium using percutaneous catheters with small injection needles. Electromechanical mapping is an excellent technique supporting the percutaneous transendocardial approach to identify ischemic territories (Smits et al. 2003). Percutaneous coronary infusion and percutaneous transendocardial delivery are most likely more appropriate in patients without a planned surgical intervention. In an experimental study, intramyocardial but not intracoronary injection of bonemarrow cells after myocardial infarction was associated with an increased risk of ventricular tachycardias (Fukushima et al. 2007). The authors observed that the intramyocardial distribution of bone-marrow cells was more homogeneous after i.c. as compared to i.m. injection, and was associated with less inflammatory response (Fukushima et al. 2007). Therefore, the most appropriate route of cell application likely depends on the clinical setting (preferably i.c. in the acute myocardial infarction) and the cell type used.

\section{Clinical trials}

Therapeutic use of bone marrow derived cells (BMCs) in the setting of acute myocardial infarction has been studied in more than 1000 patients worldwide. These BMCs include hematopoietic and endothelial progenitor cells (approximately $2-4 \%$ ), mesenchymal stem cells (MSC; $0.1 \%$ ) and a very small number of side population cells. To date four meta- analyses have been published (Abdel-Latif et al. 2007; Hristov et al. 2006; Lipinski et al. 2007; Martin-Rendon et al. 2008) suggesting the feasibility and safety of BMC application with a potential modest beneficial effects on left ventricular ejection fraction (LVEF) (an increase of approximately $3 \%$ ). A reduction in ventricular volumes; a reduction in infarct or lesion size, ranging from $3.5 \%$ to $5.6 \%$; and improved regional LV function (Lipinski et al. 2007). Although these effects on LV function are less than what was expected based on experimental studies in rodents, it should be noted that several of the established clinical therapies which do have an impact on prognosis in patients with ischemic cardiomyopathy, such as ACE inhibitor or beta-blocker therapy, are associated with a similarly small change in LV ejection fraction (Reffelmann et al. 2009). Furthermore, a patient with the greatest amount of myocardial damage displayed the greatest benefit (Janssens et al. 2006). In addition one study indicates that transplantation of bone marrow cells may have an impact on coronary flow reserve (Erbs et al. 2007). Finally, the number of injected cells may play a key role for the effects on LVEF (Martin-Rendon et al. 2008). Interestingly, the meta-analyses suggested a trend toward a reduction in recurrent MI (Martin-Rendon et al. 2008) and in the REPAIR-AMI (Intracoronary Progenitor Cells in Acute Myocardial Infarction) trial of 204 patients, even reported a significant reduction in mortality, rehospitalisation for heart failure, and repeated revascularization (Assmus et al. 2010; Schachinger et al. 2006). Of note, the overall benefit demonstrated in the meta-analyses with regard to left ventricular function needs to be tempered by the results of 3 other trials (Lunde et al. 2008; Meyer et al. 2006; Tendera et al. 2009), which showed either no benefit or an initial benefit that was not persistent beyond 6 months. In this regard, it has been suggested, that differences in cell isolation protocols may have an impact on the functional capacity of the cells in the REPAIR-AMI1 and ASTAMI (Autologous Stem Cell Transplantation in Acute Myocardial Infarction) trials and therefore may account for the conflicting results. Patients with reduced LV function may in fact have more benefit from BMC therapy as suggested by retrospective analyses of several of the aforementioned trials (Meyer et al. 2009) (Schachinger et al. 2006).

Additionally, there are also studies using enriched CD34+ or CD133+ hematopoietic and endothelial progenitor cells from bone marrow or after mobilization with the cytokine G-CSF (Losordo et al. 2007). Other studies used circulating bloodderived cells that have been isolated from mononuclear blood cells and selected ex vivo by culturing in endothelium-specific medium for 3 days. The two APOLLO trials aim to assess whether adipose tissue-derived cells enhances heart function in acute or chronic ischemia (APOLLO trials). Further clinical trials are underway investigating the use of c-kit+ cardiac stem cells in patients with chronic ischemic heart disease. Table 1 provides an overview of current ongoing cell therapy trials in patients with myocardial infarction / ischemic cardiomyopathy.

\section{Potential mechanisms mediating effects of adult stem/ progenitor cell-based therapy on cardiac function}

There are many open questions at present with respect to the understanding of mechanisms of circulating or bone marrowderived stem/progenitor cell-mediated cardiac repair (Burt et al. 2008; Landmesser 2009; Segers et al. 2008). Whereas initially, a rapid transdifferentiation of bone-marrow derived stem cells into cardiomyocytes was postulated to explain the effects on cardiac function (Orlic et al. 2001) several later studies have indicated that other mechanisms, in particular promotion of cardiac vascular growth, may mediate the observed beneficial effects on left ventricular (LV) function, likely at least in part due to paracrine effects of endothelial progenitor or bone-marrow-derived stem cells (Gnecchi et al. 2008; Murry et al. 2004). This concept was further supported by the observation that circulating endothelial progenitor cells and bone marrow-derived stem/progenitor cells may increase myocardial neovascularisation and perfusion in patients (Erbs et al. 2007). Furthermore, animal studies have suggested that bone marrow-derived progenitor cells (Templin et al. 2008; Templin et al. 2006) and human endothelial progenitor cells (Kocher et al. 2001) improve cardiac function in rodents with myocardial infarction by promotion of neovascularisation and prevention of apoptosis. It is well known from earlier studies, that myocardial capillary growth plays a critical role for maintenance of 
TABLE 1

\section{ONGOING CELL THERAPY TRIALS IN PATIENTS WITH ACUTE MYOCARDIAL INFARCTION / ISCHEMIC CARDIOMYOPATHY}

\begin{tabular}{|c|c|c|c|c|c|}
\hline $\begin{array}{l}\text { ClinicalTrials.gov } \\
\text { Identifier }\end{array}$ & Trial name & $\begin{array}{l}\text { Number of } \\
\text { patients }\end{array}$ & Cell type & Primary end point & Route of cell delivery \\
\hline \multicolumn{6}{|c|}{ Acute coronary syndrome } \\
\hline NCT00711542 & REPAIR-ACS & 100 & Bone marrow-derived progenitor cells & Coronary flow reserve in the infarct vessel & Intracoronary \\
\hline \multicolumn{6}{|c|}{ Acute myocardial infarction } \\
\hline NCT00355186 & SWISS-AMI & 150 & Bone marrow mononuclear cells & LVEF & Intracoronary \\
\hline NCT00984178 & TECAM2 & 120 & Bone marrow mononuclear cells & LVEF; Left ventricular end-systolic volume & Intracoronary \\
\hline NCT00350766 & EMRTCC & 300 & Bone marrow mononuclear cells & LVEF & Intracoronary \\
\hline NCT00684021 & The TIME Study & 120 & Bone marrow mononuclear cells & LVEF & Intracoronary \\
\hline NCT00684060 & The Late TIME Study & 87 & Bone marrow mononuclear cells & LVEF & Intracoronary \\
\hline NCT00691834 & ReNeW & 50 & Bone marrow mononuclear cells & \multicolumn{2}{|c|}{$\begin{array}{l}\text { LVEF; Occurence of arrhythmia, heart failure Intracoronary } \\
\text { and death }\end{array}$} \\
\hline NCT00874354 & REVI-TALIZE & 30 & Bone marrow mononuclear cells & Safety and feasibility; LVEF & Intracoronary \\
\hline NCT00268307 & - & 60 & Bone marrow mononuclear cells & Safety & Intracoronary \\
\hline NCT00939042 & - & 40 & Bone marrow mononuclear cells & LVEF & Intracoronary \\
\hline NCT00765453 & REGEN-AMI & 102 & Bone marrow-derived progenitor cells & LVEF & Intracoronary \\
\hline NCT00437710 & CARDIAC & 50 & Bone marrow-derived stem cells & $\begin{array}{l}\text { Mortality; Mortality and Morbidity; Left } \\
\text { ventricular function }\end{array}$ & Intracoronary \\
\hline NCT00275977 & - & 10 & Bone marrow-derived stem cells & LVEF & Intracoronary \\
\hline NCT00529932 & SELECT-AMI & 60 & CD133+ enriched bone marrow cells & $\begin{array}{l}\text { Safety; Myocardial thickening in non-viable } \\
\text { akinetic / hypokinetic LV wall segments }\end{array}$ & Intracoronary \\
\hline NCT00725738 & TRACIA STUDY & 80 & CD34+ cells & LVEF & Intracoronary \\
\hline NCT00936819 & ENACT-AMI & 100 & Early endothelial progenitor cells & LVEF & Intracoronary \\
\hline NCT00501917 & MAGIC Cell-5-Combicytokine Trial & 116 & Peripheral blood stem cells & LVEF & Intracoronary \\
\hline NCT00555828 & - & 25 & Mesenchymal precursor cells & Feasibility and safety & Transendocardial \\
\hline $\begin{array}{l}\text { NCT00877903 } \\
\text { (Osiris Therapeutics) }\end{array}$ & - & 220 & $\begin{array}{l}\text { Ex vivo cultured adult human mesenchymal stem } \\
\text { cells }\end{array}$ & Left ventricular end systolic volume & Intravenous \\
\hline NCT00893360 & CADUCEUS & 30 & Cardiosphere-derived stem cells & Safety & Intracoronary \\
\hline \multicolumn{6}{|c|}{ Ischemic cardiomyopathy } \\
\hline NCT00326989 & Cellwave Study & 100 & Bone marrow progenitor cells & LVEF & Intracoronary \\
\hline NCT00824005 & FOCUS & 87 & Bone marrow mononuclear cells & $\begin{array}{l}\text { maximal oxygen consumption, } \\
\text { left ventricular end systolic volume, } \\
\text { reversible defect size }\end{array}$ & Transendocardial \\
\hline NCT00810238 & C-Cure & 240 & Bone marrow-derived cardiopoietic cells & LVEF & Transendocardial \\
\hline NCT00690209 & - & 30 & Bone marrow-derived stem cells & Left ventricular volumes and contractility & $\begin{array}{l}\text { Transepicardial during } \\
\text { CABG }\end{array}$ \\
\hline NCT00418418 & - & 60 & Bone marrow-derived stem cells & LVEF & $\begin{array}{l}\text { Transepicardial during } \\
\text { CABG }\end{array}$ \\
\hline NCT01049867 & - & 10 & CD133+ Endothelial precursor cells & Regional and global myocardial contractility & Intracoronary \\
\hline NCT01033617 & IMPACT-CABG & 20 & CD133+ bone marrow stem cells & $\begin{array}{l}\text { Freedom from major adverse cardiac event; } \\
\text { Freedom from major arrhythmia }\end{array}$ & $\begin{array}{l}\text { Transepicardial during } \\
\text { CABG }\end{array}$ \\
\hline NCT00950274 & PERFECT & 142 & CD133+ bone marrow stem cells & LVEF & $\begin{array}{l}\text { Transepicardial during } \\
\text { CABG }\end{array}$ \\
\hline NCT00462774 & Cardio133 & 60 & CD133+ marrow cells & LVEF & $\begin{array}{l}\text { Transepicardial during } \\
\text { CABG }\end{array}$ \\
\hline NCT00346177 & - & 30 & CD34+ cells & Safety, LVEF, heart failure symptoms & Transendocardial \\
\hline NCT00620048 & - & 10 & CD34+ cells & Safety, LVEF, heart failure symptoms & Transendocardial \\
\hline NCT00221182 & - & 10 & CD34+ cells & $\begin{array}{l}\text { Myocardial perfusion abnormality/ } \\
\text { Safety }\end{array}$ & \\
\hline NCT00721045 & - & 60 & Mesenchymal precursor cells & Safety and feasibility & Transendocardial \\
\hline NCT01076920 & MESAMI & 10 & Mesenchymal stem cells & Safety and feasibility & Transendocardial \\
\hline NCT01087996 & The POSEIDON-Pilot Study & 30 & Bone-marrow derived mesenchymal stem cells & TE-SAE & Transendocardial \\
\hline NCT00768066 & TAC-HFT & 60 & Mesenchymal cells / Bone marrow cells & TE-SAE & Transendocardial \\
\hline NCT00587990 & PROMETHEUS & 45 & Mesenchymal stem cells & Serious adverse events & $\begin{array}{l}\text { Transepicardial during } \\
\text { CABG }\end{array}$ \\
\hline NCT00908622 & PERCUTANEO & 50 & Skeletal myoblasts & LVEF; wall motion score index & $\begin{array}{l}\text { Percutaneous } \\
\text { Implantation }\end{array}$ \\
\hline NCT00526253 & MARVEL & 390 & Skeletal myoblasts & $\begin{array}{l}\text { 6-minute walk test; Quality of Life } \\
\text { Questionnaire }\end{array}$ & Transendocardial \\
\hline NCT00474461 & SCIPIO & 40 & Cardiac stem cells & Safety/Efficacy Study & Intracoronary \\
\hline NCT00981006 & ALCADIA & 6 & Cardiac-derived stem cells & Safety & $\begin{array}{l}\text { Transepicardial during } \\
\text { CABG }\end{array}$ \\
\hline
\end{tabular}


cardiac function (Giordano et al. 2001). In addition to enhanced neovascularization, paracrine factors released by the incorporated cells may beneficially influence cardiac repair by protecting cardiovascular cells from apoptotic stimuli or even by activating cardiacresident stem cells to enhance the endogenous repair capacity (Uemura et al. 2006; Urbich et al. 2005). Paracrine mechanisms may additionally prevent inflammation, fibrosis and reactive hypertrophy (Burchfield et al. 2008). Moreover, the injection of conditioned medium from MSCs results in the improvements of left ventricular function and reduced apoptosis (Gnecchi et al. 2005). In a further article, SFRP2 (secreted frizzled-related protein II), which modulates the Wnt (winglesstype MMTV integration site family) pathway and the expression of antiapoptotic genes, was shown to be the main factor released by AKT-1(v-akt murine thymoma viral oncogene homolog 1)-enriched MSCs (Mirotsou et al. 2007). Recently, we analyzed the secreted proteome of a hematopoietic progenitor cell line which exert modulating effects on tissue repair and regeneration. In this study a subset of 95 different proteins were identified in a mass spectrometry based approach whereas the cytokines IL- 6 and IL-13 and the chemokines MCP-1, MCP-3, MIP1-a, and MIP1-b were identified using an immunological approach (Luecke et al. 2010). Furthermore, experimental data have shown that interleukin 10 from transplanted bone marrow mononuclear cells may play a role in cardiac protection after MI (Burchfield et al. 2008). Additionally, other cytokines and growth factors from transplanted progenitor cells may exert important paracrine effects like vascular endothelial growth factor, stromal cell-derived factor, angiopoietin 1, hepatocyte growth factor, insulinlike growth factor 1, and periostin, among others (Kinnaird et al. 2004; Uemura et al. 2006; Urbich et al. 2005). Although the direct effects of cell therapy are not entirely understood, the majority of studies suggest that stem/progenitor cells may have a beneficial effect on cardiac function.

\section{Limitations of current cell-based treatment approaches}

There is currently a limited knowledge on the role of the required number and function of bone marrow cells needed for an optimal effect on cardiac repair. Low cell dosages might in fact limit the efficacy of bone marrow cell therapy. For example, in the ASTAMI trial, the median number of mononuclear cells injected was $68 \mathrm{x}$ $10^{6}$, and the median number of CD34+ cells was $0.7 \times 10^{6}$. There were no significant differences between the BMC and control group in changes in LVEF, end-diastolic volume, or infarct size (Lunde et al. 2006). In the BOOST trial, the average number of mononuclear $\mathrm{BM}$ cells was $24.6 \times 10^{8}$, and the number of $\mathrm{CD} 34^{+}$cells was 9.5 $x 10^{6}$. Six months after randomisation, global LVEF increased from $50.0 \%$ to $56.7 \%(P=0.0026)$, albeit this difference was not maintained at long-term follow-up (Wollert et al. 2004). In the TOPCAREAMI trial, the average number of mononuclear BM cells was 24.5 $\times 10^{7}$, and the number of CD34+ cells was $7 \times 10^{6}$. In patients receiving progenitor cells, global LVEF increased from $51.6 \%$ to $60.1 \%(P=0.003)$ (Schachinger et al. 2006). To treat a patient of 80 $\mathrm{kg}$ with a high dose cell strategy as described in some animal studies $\left(1 \times 10^{7}\right.$ cells $\left./ 25 \mathrm{~g}\right)$ would require $32 \times 10^{9} \mathrm{CD} 34^{+}$cells (adjusted to body weight), which exceeds the number of HPCs used in clinical trials by a factor of $\sim 3000$ (Assmus et al. 2002). Therefore, strategies allowing rapid ex vivo progenitor cell expansion may improve cell-based clinical treatment regimens (Templin et al., 2008).

Another potential reason for discrepancies between experimental and clinical studies with respect to the impact of circulating or bone marrow-derived stem/progenitor cell therapy on cardiac function is related to the fact, that the effect of stem/progenitor cells obtained from young healthy rodents in experimental studies is compared with effects of stem/progenitor cells obtained from older patients with chronic coronary disease in clinical studies. In support of this concept, a substantially impaired in vivo vascular repair capacity of stem/progenitor cells derived from patients with cardiovascular risk factors as compared to healthy subjects has been observed (Giannotti et al. 2010; Sorrentino et al. 2007), and very recently a severely reduced vascular and cardiac repair capacity of stem/progenitor cells derived from patients with ischemic cardiomyopathy.

Additionally, cell therapy is currently limited by low rates of cell engraftment after intracoronary delivery and poor cell survival after intramyocardial injections (Hofmann et al. 2005; Menasche 2008; Schachinger et al. 2008). Furthermore, the amount of circulating progenitor cells in patients with cardiac ischemic disease comorbidities such as diabetes mellitus, hypertension and hypercholesterolemia is reduced (Imanishi et al. 2005; Vasa et al. 2001). This is problematic as this cohort is essentially the very one that would need to be treated with progenitor cells. These challenges require further research to enhance the therapeutic efficiency of stem and progenitor cells in the treatment of ischemic heart disease. This includes the use of more potent cells with a higher cardiac regeneration capacity (for instance induced pluripotent stem cells) and strategies for improving cell homing, survival,, engraftment and repair capacity, of transplanted cells.

\section{Future directions of cell based-therapy for ischemic heart disease}

To implement cell based-therapy for ischemic heart disease into clinical routine, many questions need to be addressed. Several studies have indicated a reduced cardiac and vascular repair capacity of patient-derived adult stem/progenitor cells as compared to cells obtained from healthy subjects (Giannotti et al. 2010; Sorrentino et al. 2007). Therefore, the mechanisms leading to stem/progenitor cell dysfunction need to be better characterized and will provide interesting novel approaches to optimize cellbased treatment approaches. Moreover, strategies to improve cardiac homing and engraftment of stem/progenitor cells may optimize the effect the results of this treatment approach (Pons et al. 2008; Pons et al. 2009; Tang et al. 2009; Zhao et al. 2009).

One interesting strategy for the improvement of current cellbased approaches may be the combination of cell- and gene therapy (Fig. 1). In this regard, we have demonstrated long-term self renewal and unlimited expansion of hematopoietic progenitor cells using human $\beta$-catenin gene transfer (Templin et al. 2008). Administration of defined $\beta$-catenin-HPCs after Ml reduces infarct size and improves left ventricular function and dimensions in a threshold-dependent manner (Templin et al. 2008). This effect is associated with improved angiogenesis and reduced apoptosis in the infarct border zone. Furthermore, $\beta$-catenin-HPCs have greater therapeutic efficacy than control-transduced HPCs (GFP-HPCs), demonstrating a beneficial effect of $\beta$-catenin transduction on myocardial repair (Templin et al. 2008). Other recent studies have 


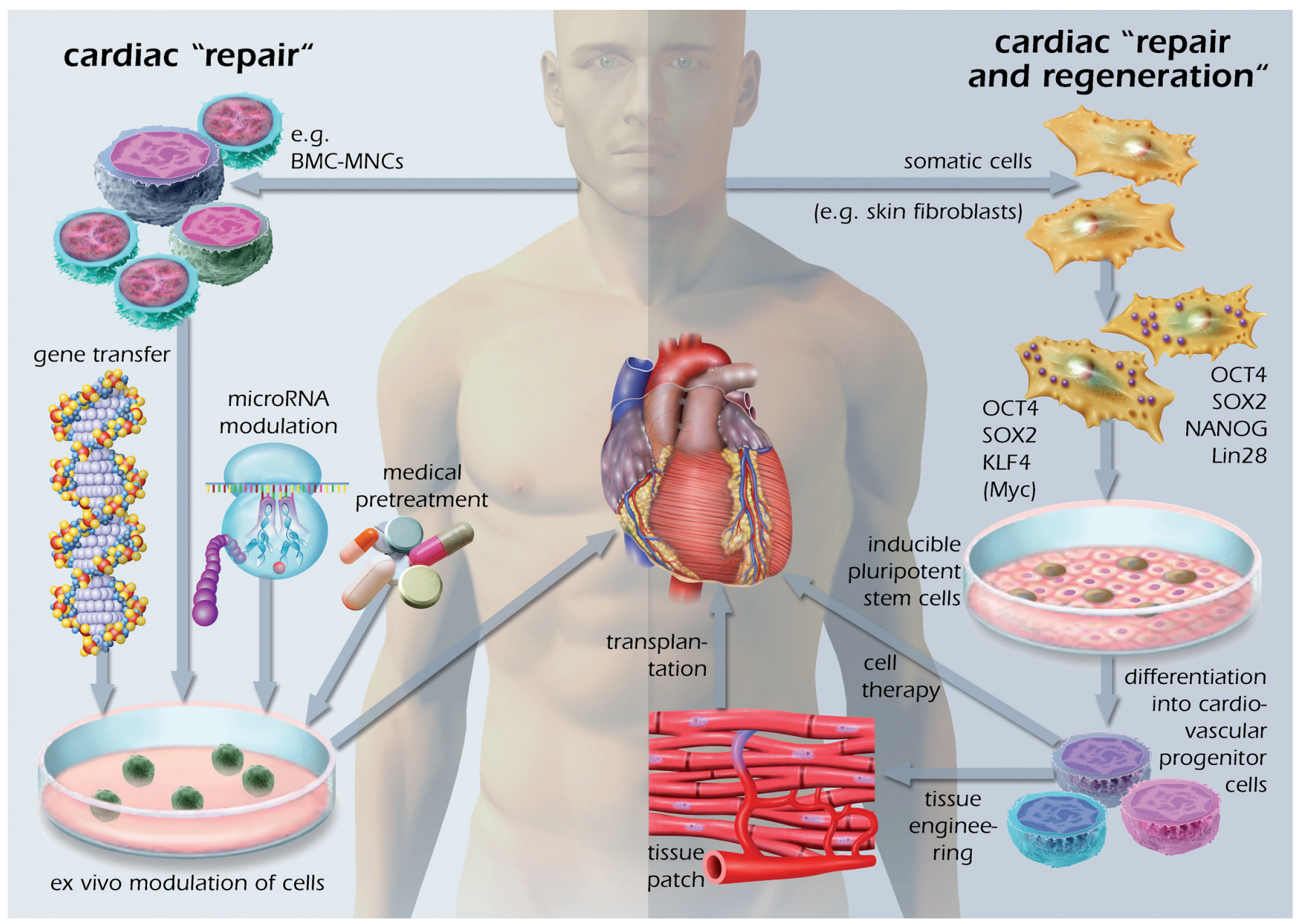

Fig.1. Future developments of cell-based therapy for ischemic cardiomyopathy (modified after Templin et al. 2010). Ex vivo modulation (e.g. microRNA modulation or combined gene and cell-therapy) of bone marrow derived progenitor cells may be used to improve current adult cell treatment strategies. Inducible pluripotent stem cells have the ability to differentiate into cardiovasular cells and exhibits great potential for cardiac regeneration.

investigated specific protein expression through ex vivo modifications of receptors and molecules involved in progenitor cell paracrine signaling, homing, and survival. In this regard, MSCs have been modified to overexpress growth factors (e.g. VEGF) (Yang et al. 2007) and ischemia protective proteins (e.g. heme oxygenase-1) (Tang et al. 2005), upregulate homing receptors (Cheng et al. 2008) or influence survival signaling pathways (e.g. Akt) (Mangi et al. 2003).

A recent interesting study combined a genetic and pharmacologic inhibition of dipeptidylpeptidase IV with G-CSF-mediated stem cell mobilization after myocardial infarction in mice. This approach leads to increased myocardial homing of circulating CXCR-4+ stem cells, and improved heart function and survival (Zaruba et al. 2009).

Pretreatment of endothelial progenitor cells with statins, eNOSoverexpression of PPAR-gamma agonists before transfer increases their migratory, invasive, and neovascularization capacity - effects that are mediated by activation of endothelial nitric oxide synthase (Shao et al. 2008; Spyridopoulos et al. 2004). Similary, own results showed that prestimulation of endothelial progenitor cells from diabetic individuals with the peroxisome proliferator activated receptor $\gamma$-agonist rosiglitazone, enhances nitric oxide availability and the in vivo endothelial repair capacity of these cells (Sorrentino et al. 2007). MicroRNAs have been identified as unexpectedly potent regulators in cardiovascular biology, controlling vascular growth, endothelial NO synthase and stem cell differentiation and may be interesting targets to optimize cell-based therapies (Suarez et al. 2007; Suarez et al. 2009; van Rooij et al. 2008).

\section{Conclusion}

Development of cell-based strategies for cardiac repair for the use in clinical routine is an exciting and challenging task. The concept of cardiac regeneration or rejuvenation and protection via paracrine mechanisms responses to reduce cardiomyocyte apoptosis and increase angiogenesis needs to be further developed and optimized, and represents one important line of current research. One such approach represents the combination of cell and gene therapy, by either transduction of genes into stem cells or modifying stem cells as vectors for drug delivery. Moreover, novel cell 
types with a true cardiomyocyte transdifferentiation potential such as iPS provide another important line in the development of cellbased approaches for cardiac repair (Fig. 1). Upscaling and safety of such an approach represent important challenges to be solved.

\section{Acknowledgements}

This work was supported by a grant of the Swiss National Research Foundation "Sonderprogramm Universitäre Medizin"[Nr. 33CM30-124112/ 1], Swiss National Research Foundation grant (310000-122339), and the Zurich Center for Integrative Human Physiology.

\section{References}

ABDEL-LATIF A, BOLLI R, TLEYJEH IM, MONTORI VM, PERIN EC, HORNUNG CA, ZUBA-SURMA EK, AL-MALLAH M, DAWN B (2007). Adult bone marrowderived cells for cardiac repair: a systematic review and meta-analysis. Arch Intern Med 167: 989-997.

ABKOWITZ JL, CATLIN SN, MCCALLIE MT, GUTTORP P (2002). Evidence that the number of hematopoietic stem cells per animal is conserved in mammals. Blood 100: 2665-2667.

AICHER A, BRENNER W, ZUHAYRA M, BADORFF C, MASSOUDIS, ASSMUSB, ECKEY T, HENZE E, ZEIHER AM, DIMMELER S (2003). Assessment of the tissue distribution of transplanted human endothelial progenitor cells by radioactive labeling. Circulation 107: 2134-2139.

AMADO LC, SCHULERI KH, SALIARIS AP, BOYLE AJ, HELM R, OSKOUEI B, CENTOLA M, ENEBOE V, YOUNG R, LIMA JA, LARDO AC, HELDMAN AW, HARE JM (2006). Multimodality noninvasive imaging demonstrates in vivo cardiac regeneration after mesenchymal stem cell therapy. J Am Coll Cardiol 48: 2116-2124

ASSMUSB, FISCHER-RASOKATU, HONOLD J, SEEGER FH, FICHTLSCHERER S, TONN T, SEIFRIED E, SCHACHINGER V, DIMMELER S, ZEIHER AM (2007). Transcoronary transplantation of functionally competent BMCs is associated with a decrease in natriuretic peptide serum levels and improved survival of patients with chronic postinfarction heart failure: results of the TOPCARECHD Registry. Circ Res 100: 1234-1241.

ASSMUS B, ROLF A, ERBS S, ELSASSER A, HABERBOSCH W, HAMBRECHT $R$, TILLMANNS H, YU J, CORTI R, MATHEY DG, HAMM CW, SUSELBECK T, TONN T, DIMMELER S, DILL T, ZEIHER AM, SCHACHINGER V (2010). Clinical outcome 2 years after intracoronary administration of bone marrowderived progenitor cells in acute myocardial infarction. Circ Heart Fail 3: 89-96.

ASSMUS B, SCHACHINGER V, TEUPE C, BRITTEN M, LEHMANN R, DOBERT $\mathrm{N}$, GRUNWALD F, AICHER A, URBICH C, MARTIN H, HOELZER D, DIMMELER S, ZEIHER AM (2002). Transplantation of Progenitor Cells and Regeneration Enhancement in Acute Myocardial Infarction (TOPCARE-AMI). Circulation 106: 3009-3017.

BARBASH IM, CHOURAQUI P, BARON J, FEINBERG MS, ETZION S, TESSONE A, MILLER L, GUETTA E, ZIPORI D, KEDES LH, KLONER RA, LEOR J (2003). Systemic delivery of bone marrow-derived mesenchymal stem cells to the infarcted myocardium: feasibility, cell migration, and body distribution. Circulation 108: 863-868.

BELTRAMI AP, BARLUCCHI L, TORELLA D, BAKER M, LIMANA F, CHIMENTI S, KASAHARA H, ROTA M, MUSSO E, URBANEK K, LERI A, KAJSTURA J, NADAL-GINARD B, ANVERSA P (2003). Adult cardiac stem cells are multipotent and support myocardial regeneration. Cell 114: 763-776.

BURCHFIELD JS, IWASAKI M, KOYANAGI M, URBICH C, ROSENTHAL N, ZEIHER AM, DIMMELER S (2008). Interleukin-10 from transplanted bone marrow mononuclear cells contributes to cardiac protection after myocardial infarction. Circ Res 103: 203-211.

BURT RK, LOH Y, PEARCE W, BEOHAR N, BARR WG, CRAIG R, WEN Y, RAPP JA, KESSLER J (2008). Clinical applications of blood-derived and marrowderived stem cells for nonmalignant diseases. JAMA 299: 925-936.

CASPI O, HUBER I, KEHAT I, HABIB M, ARBEL G, GEPSTEIN A, YANKELSON L, ARONSON D, BEYAR R, GEPSTEIN L (2007). Transplantation of human embryonic stem cell-derived cardiomyocytes improves myocardial performance in infarcted rat hearts. J Am Coll Cardiol 50: 1884-1893.

CHALLEN GA, LITTLE MH'(2006). A side order of stem cells: the SP phenotype.
Stem Cells 24: 3-12

CHENG Z, OU L, ZHOU X, LI F, JIA X, ZHANG Y, LIU X, LI Y, WARD CA, MELO LG, KONG D (2008). Targeted migration of mesenchymal stem cells modified with CXCR4 gene to infarcted myocardium improves cardiac performance. Mol Ther 16: 571-579.

CONGET PA, MINGUELL JJ (1999). Phenotypical and functional properties of human bone marrow mesenchymal progenitor cells. J Cell Physiol 181: 67-73.

CRISOSTOMO PR, ABARBANELL AM, WANG M, LAHM T, WANG Y, MELDRUM DR (2008). Embryonic stem cells attenuate myocardial dysfunction and inflammation after surgical global ischemia via paracrine actions. Am J Physiol Heart Circ Physiol 295: H1726-1735.

DIB N, DINSMORE J, LABABIDI Z, WHITE B, MORAVEC S, CAMPBELL A, ROSENBAUM A, SEYEDMADANI K, JABER WA, RIZENHOUR CS, DIETHRICH $E$ (2009). One-year follow-up of feasibility and safety of the first U.S., randomized, controlled study using 3-dimensional guided catheter-based delivery of autologous skeletal myoblasts for ischemic cardiomyopathy (CAuSMIC study) JACC Cardiovasc Interv 2: 9-16.

DOMINICI M, LE BLANC K, MUELLER I, SLAPER-CORTENBACH I, MARINI F, KRAUSE D, DEANS R, KEATING A, PROCKOP D, HORWITZ E (2006). Minimal criteria for defining multipotent mesenchymal stromal cells. The International Society for Cellular Therapy position statement. Cytotherapy 8: 315317.

ERBS S, LINKE A, SCHACHINGER V, ASSMUS B, THIELE H, DIEDERICH KW, HOFFMANN C, DIMMELER S, TONN T, HAMBRECHT R, ZEIHER AM, SCHULER G (2007). Restoration of microvascular function in the infarct-related artery by intracoronary transplantation of bone marrow progenitor cells in patients with acute myocardial infarction: the Doppler Substudy of the Reinfusion of Enriched Progenitor Cells and Infarct Remodeling in Acute Myocardial Infarction (REPAIR-AMI) trial. Circulation 116: 366-374.

FORD ES, AJANI UA, CROFT JB, CRITCHLEY JA, LABARTHE DR, KOTTKE TE, GILES WH, CAPEWELL S (2007). Explaining the decrease in U.S. deaths from coronary disease, 1980-2000. N Engl J Med 356: 2388-2398.

FREYMAN T, POLIN G, OSMAN H, CRARY J, LU M, CHENG L, PALASIS M, WILENSKY RL (2006). A quantitative, randomized study evaluating three methods of mesenchymal stem cell delivery following myocardial infarction. Eur Heart J 27: 1114-1122.

FUKUSHIMA S, VARELA-CARVER A, COPPEN SR, YAMAHARA K, FELKIN LE, LEE J, BARTON PJ, TERRACCIANO CM, YACOUB MH, SUZUKI K (2007). Direct intramyocardial but not intracoronary injection of bone marrow cells induces ventricular arrhythmias in a rat chronic ischemic heart failure model. Circulation 115: 2254-2261.

GEOGHEGAN E, BYRNES L (2008). Mouse induced pluripotent stem cells. Int J Dev Biol 52: 1015-1022.

GIANNOTTI G, DOERRIES C, MOCHARLA PS, MUELLER MF, BAHLMANN FH, HORVÀTHT, JIANG H, SORRENTINO SA, STEENKEN N, MANES C, MARZILLI M, RUDOLPH KL, LÜSCHER TF, DREXLER H, LANDMESSER U (2010). Impaired endothelial repair capacity of early endothelial progenitor cells in prehypertension: relation to endothelial dysfunction. Hypertension 55: 13891397.

GIORDANO FJ, GERBER HP, WILLIAMS SP, VANBRUGGEN N, BUNTING S, RUIZ-LOZANO P, GU Y, NATH AK, HUANG Y, HICKEY R, DALTON N, PETERSON KL, ROSS J, JR., CHIEN KR, FERRARA N (2001). A cardiac myocyte vascular endothelial growth factor paracrine pathway is required to maintain cardiac function. Proc Natl Acad Sci USA 98: 5780-5785.

GNECCHI M, HE H, LIANG OD, MELO LG, MORELLO F, MU H, NOISEUX N, ZHANG L, PRATT RE, INGWALL JS, DZAU VJ (2005). Paracrine action accounts for marked protection of ischemic heart by Akt-modified mesenchymal stem cells. Nat Med 11: 367-368.

GNECCHI M, ZHANG Z, NI A, DZAU VJ (2008). Paracrine mechanisms in adult stem cell signaling and therapy. Circ Res 103: 1204-1219.

GRUH I, BEILNER J, BLOMER U, SCHMIEDL A, SCHMIDT-RICHTER I, KRUSE ML, HAVERICH A, MARTIN U (2006). No evidence of transdifferentiation of human endothelial progenitor cells into cardiomyocytes after coculture with neonatal rat cardiomyocytes. Circulation 113: 1326-1334.

HIERLIHY AM, SEALE P, LOBE CG, RUDNICKI MA, MEGENEY LA (2002). The post-natal heart contains a myocardial stem cell population. FEBS Lett 530 : 239-243. 
HIRSCH A, NIJVELDT R, VAN DER VLEUTEN PA, BIEMOND BJ, DOEVENDANS PA, VAN ROSSUM AC, TIJSSEN JG, ZIJLSTRA F, PIEKJJ (2006). Intracoronary infusion of autologous mononuclear bone marrow cells or peripheral mononuclear blood cells after primary percutaneous coronary intervention: rationale and design of the HEBE trial-a prospective, multicenter, randomized trial. $\mathrm{Am}$ Heart J 152: 434-441.

HOFMANN M, WOLLERT KC, MEYER GP, MENKE A, ARSENIEV L, HERTENSTEIN B, GANSER A, KNAPP WH, DREXLER H (2005). Monitoring of bone marrow cell homing into the infarcted human myocardium. Circulation 111: 2198-2202.

HRISTOV M, HEUSSEN N, SCHOBER A, WEBER C (2006). Intracoronary infusion of autologous bone marrow cells and left ventricular function after acute myocardial infarction: a meta-analysis. J Cell Mol Med 10: 727-733.

HUR J, YOON CH, KIM HS, CHOI JH, KANG HJ, HWANG KK, OH BH, LEE MM, PARK YB (2004). Characterization of two types of endothelial progenitor cells and their different contributions to neovasculogenesis. Arterioscler Thromb Vasc Biol 24: 288-293.

IMANISHI T, MORIWAKI C, HANO T, NISHIO I (2005). Endothelial progenitor cell senescence is accelerated in both experimental hypertensive rats and patients with essential hypertension. J Hypertens 23: 1831-1837.

IWASAKI H, KAWAMOTO A, WILLWERTH C, HORII M, OYAMADA A, AKIMARU H, SHIBATA T, HIRAI H, SUEHIRO S, WNENDT S, FODOR WL, ASAHARA T (2009). Therapeutic potential of unrestricted somatic stem cells isolated from placental cord blood for cardiac repair post myocardial infarction. Arterioscler Thromb Vasc Biol 29: 1830-1835.

JACKSON KA, MAJKA SM, WANG H, POCIUS J, HARTLEY CJ, MAJESKY MW, ENTMAN ML, MICHAEL LH, HIRSCHI KK, GOODELL MA (2001). Regeneration of ischemic cardiac muscle and vascular endothelium by adult stem cells. J Clin Invest 107: 1395-1402.

JANSSENS S, DUBOIS C, BOGAERT J, THEUNISSEN K, DEROOSE C, DESMET W, KALANTZI M, HERBOTS L, SINNAEVE P, DENS J, MAERTENS J, RADEMAKERS F, DYMARKOWSKI S, GHEYSENS O, VAN CLEEMPUT J, BORMANS G, NUYTS J, BELMANS A, MORTELMANS L, BOOGAERTS M, VAN DE WERF F (2006). Autologous bone marrow-derived stem-cell transfer in patients with ST-segment elevation myocardial infarction: double-blind, randomised controlled trial. Lancet 367: 113-121.

KIM BO, TIAN H, PRASONGSUKARN K, WU J, ANGOULVANT D, WNENDT S, MUHS A, SPITKOVSKY D, LI RK (2005). Cell transplantation improves ventricular function after a myocardial infarction: a preclinical study of human unrestricted somatic stem cells in a porcine model. Circulation 112: 196-104.

KIM D, KIM CH, MOON JI, CHUNG YG, CHANG MY, HAN BS, KO S, YANG E, CHA KY, LANZA R, KIM KS (2009). Generation of human induced pluripotent stem cells by direct delivery of reprogramming proteins. Cell Stem Cell 4: 472-476.

KINNAIRD T, STABILE E, BURNETT MS, LEE CW, BARR S, FUCHS S, EPSTEIN SE (2004). Marrow-derived stromal cells express genes encoding a broad spectrum of arteriogenic cytokines and promote in vitro and in vivo arteriogenesis through paracrine mechanisms. Circ Res 94: 678-685.

KOCHER AA, SCHUSTER MD, SZABOLCS MJ, TAKUMA S, BURKHOFF D, WANG J, HOMMA S, EDWARDS NM, ITESCU S (2001). Neovascularization of ischemic myocardium by human bone-marrow-derived angioblasts prevents cardiomyocyte apoptosis, reduces remodeling and improves cardiac function. Nat Med 7: 430-436.

LAFLAMME MA, CHEN KY, NAUMOVA AV, MUSKHELI V, FUGATE JA, DUPRAS SK, REINECKE H, XU C, HASSANIPOUR M, POLICE S, O'SULLIVAN C, COLLINS L, CHENY, MINAMI E, GILL EA, UENO S, YUAN C, GOLD J, MURRY CE (2007). Cardiomyocytes derived from human embryonic stem cells in prosurvival factors enhance function of infarcted rat hearts. Nat Biotechnol 25: 1015-1024

LANDMESSER U (2009). Bone marrow cell therapy after myocardial infarction. What should we select? Eur Heart J 30: 1310-1312.

LANDMESSER U, DREXLER H (2005). Chronic heart failure: an overview of conventional treatment versus novel approaches. Nat Clin Pract Cardiovasc Med 2: 628-638.

LANDMESSER U, ENGBERDING N, BAHLMANN FH, SCHAEFER A, WIENCKE A, HEINEKE A, SPIEKERMANN S, HILFIKER-KLEINER D, TEMPLIN C, KOTLARZ D, MUELLER M, FUCHS M, HORNIG B, HALLER H, DREXLER H (2004). Statin-induced improvement of endothelial progenitor cell mobilization, myocardial neovascularization, left ventricular function, and survival after experimental myocardial infarction requires endothelial nitric oxide synthase. Circulation 110: 1933-1939.

LANDMESSER U, WOLLERT KC, DREXLER H (2009). Potential novel pharmacological therapies for myocardial remodelling. Cardiovasc Res 81: 519-527.

LAUGWITZ KL, MORETTI A, LAM J, GRUBER P, CHEN Y, WOODARD S, LIN LZ, CAI CL, LU MM, RETH M, PLATOSHYN O, YUAN JX, EVANS S, CHIEN KR (2005). Postnatal isl1+ cardioblasts enter fully differentiated cardiomyocyte lineages. Nature 433: 647-653.

LI Z, LEE A, HUANG M, CHUN H, CHUNG J, CHU P, HOYT G, YANG P, ROSENBERG J, ROBBINS RC, WU JC (2009). Imaging survival and function of transplanted cardiac resident stem cells. J Am Coll Cardiol 53: 1229-1240.

LIPINSKI MJ, BIONDI-ZOCCAI GG, ABBATE A, KHIANEY R, SHEIBAN I, BARTUNEK J, VANDERHEYDEN M, KIM HS, KANG HJ, STRAUER BE, VETROVEC GW (2007). Impact of intracoronary cell therapy on left ventricular function in the setting of acute myocardial infarction: a collaborative systematic review and meta-analysis of controlled clinical trials. J Am Coll Cardiol50: 17611767.

LOSORDO DW, SCHATZ RA, WHITE CJ, UDELSON JE, VEERESHWARAYYA V, DURGIN M, POH KK, WEINSTEIN R, KEARNEY M, CHAUDHRY M, BURG A EATON L, HEYD L, THORNE T, SHTURMAN L, HOFFMEISTER P, STORY K ZAK V, DOWLING D, TRAVERSE JH, OLSON RE, FLANAGAN J, SODANO D, MURAYAMA T, KAWAMOTO A, KUSANO KF, WOLLINS J, WELT F, SHAH P, SOUKAS P, ASAHARA T, HENRY TD (2007). Intramyocardial transplantation of autologous CD34+ stem cells for intractable angina: a phase I/lla doubleblind, randomized controlled trial. Circulation 115: 3165-3172.

LUECKE N, TEMPLIN C, MUETZELBURG MV, NEUMANN D, JUST I, PICH A (2010). Secreted proteome of the murine multipotent hematopoietic progenitor cell line DKmix. Rapid Commun Mass Spectrom 24: 561-570.

LUNDE K, SOLHEIM S, AAKHUS S, ARNESEN H, ABDELNOOR M, EGELAND T, ENDRESEN K, ILEBEKK A, MANGSCHAU A, FJELD JG, SMITH HJ, TARALDSRUD E, GROGAARD HK, BJORNERHEIM R, BREKKE M, MULLER C, HOPP E, RAGNARSSON A, BRINCHMANN JE, FORFANG K (2006). Intracoronary injection of mononuclear bone marrow cells in acute myocardial infarction. N Engl J Med 355: 1199-1209.

LUNDE K, SOLHEIM S, FORFANG K, ARNESEN H, BRINCH L, BJORNERHEIM R, RAGNARSSON A, EGELAND T, ENDRESEN K, ILEBEKK A, MANGSCHAU A, AAKHUS S (2008). Anterior myocardial infarction with acute percutaneous coronary intervention and intracoronary injection of autologous mononuclear bone marrow cells: safety, clinical outcome, and serial changes in left ventricular function during 12-months' follow-up. J Am Coll Cardiol 51: 674-676.

MAKELA J, ANTTILA V, YLITALO K, TAKALO R, LEHTONEN S, MAKIKALLIO T, NIEMELA E, DAHLBACKA S, TIKKANEN J, KIVILUOMA K, JUVONEN T, LEHENKARI P (2009). Acute homing of bone marrow-derived mononuclear cells in intramyocardial vs. intracoronary transplantation. Scand Cardiovasc $J$ 43: $366-373$

MAKINO S, FUKUDA K, MIYOSHI S, KONISHI F, KODAMA H, PAN J, SANO M, TAKAHASHI T, HORI S, ABE H, HATA J, UMEZAWA A, OGAWA S (1999). Cardiomyocytes can be generated from marrow stromal cells in vitro. $J$ Clin Invest 103: 697-705.

MANGI AA, NOISEUX N, KONG D, HE H, REZVANI M, INGWALL JS, DZAU VJ (2003). Mesenchymal stem cells modified with Akt prevent remodeling and restore performance of infarcted hearts. Nat Med 9: 1195-1201.

MARTIN-RENDON E, BRUNSKILL SJ, HYDE CJ, STANWORTH SJ, MATHUR A WATT SM (2008). Autologous bone marrow stem cells to treat acute myocardial infarction: a systematic review. Eur Heart J 29: 1807-1818.

MAURITZ C, SCHWANKE K, REPPEL M, NEEF S, KATSIRNTAKI K, MAIER LS NGUEMO F, MENKE S, HAUSTEIN M, HESCHELER J, HASENFUSS G, MARTIN U (2008). Generation of functional murine cardiac myocytes from induced pluripotent stem cells. Circulation 118: 507-517.

MELO LG, PACHORI AS, KONG D, GNECCHI M, WANG K, PRATT RE, DZAU VJ (2004). Gene and cell-based therapies for heart disease. FASEB J 18: 648-663.

MENASCHE P (2008). Skeletal myoblasts and cardiac repair. J Mol Cell Cardiol 45: 545-553.

MENASCHE P, ALFIERI O, JANSSENS S, MCKENNA W, REICHENSPURNER H, TRINQUART L, VILQUIN JT, MAROLLEAU JP, SEYMOUR B, LARGHERO J, LAKE S, CHATELLIER G, SOLOMON S, DESNOS M, HAGEGE AA (2008). The 
Myoblast Autologous Grafting in Ischemic Cardiomyopathy (MAGIC) trial: first randomized placebo-controlled study of myoblast transplantation. Circulation 117: 1189-1200.

MENASCHE P, HAGEGE AA, VILQUIN JT, DESNOS M, ABERGEL E, POUZET B, BEL A, SARATEANU S, SCORSIN M, SCHWARTZ K, BRUNEVAL P, BENBUNAN M, MAROLLEAU JP, DUBOC D (2003). Autologous skeletal myoblast transplantation for severe postinfarction left ventricular dysfunction. $J$ Am Coll Cardiol 41: 1078-1083.

MESSINA E, DE ANGELIS L, FRATI G, MORRONE S, CHIMENTI S, FIORDALISO F, SALIO M, BATTAGLIA M, LATRONICO MV, COLETTA M, VIVARELLI E, FRATI L, COSSU G, GIACOMELLO A (2004). Isolation and expansion of adult cardiac stem cells from human and murine heart. Circ Res 95: 911-921.

MEYER GP, WOLLERT KC, LOTZ J, PIRR J, RAGER U, LIPPOLT P, HAHN A, FICHTNER S, SCHAEFER A, ARSENIEV L, GANSER A, DREXLER H (2009). Intracoronary bone marrow cell transfer after myocardial infarction: 5-year follow-up from the randomized-controlled BOOST trial. Eur Heart J 30: 29782984.

MEYER GP, WOLLERT KC, LOTZ J, STEFFENS J, LIPPOLT P, FICHTNER S, HECKER H, SCHAEFER A, ARSENIEV L, HERTENSTEIN B, GANSER A, DREXLER H (2006). Intracoronary bone marrow cell transfer after myocardial infarction: eighteen months' follow-up data from the randomized, controlled BOOST (BOne marrOw transfer to enhance ST-elevation infarct regeneration) trial. Circulation 113: 1287-1294.

MIN JY, YANG Y, SULLIVAN MF, KE Q, CONVERSO KL, CHEN Y, MORGAN JP, XIAO YF (2003). Long-term improvement of cardiac function in rats after infarction by transplantation of embryonic stem cells. J Thorac Cardiovasc Surg 125: 361-369.

MIROTSOU M, ZHANG Z, DEB A, ZHANG L, GNECCHI M, NOISEUX N, MU H, PACHORI A, DZAU V (2007). Secreted frizzled related protein 2 (Sfrp2) is the key Akt-mesenchymal stem cell-released paracrine factor mediating myocardial survival and repair. Proc Natl Acad Sci USA 104: 1643-1648.

MOSCOSOI, BARALLOBRE J, DE ILARDUYA OM, ANON P, FRAGA M, CALVINO R, ALDAMA G, DOMENECH N (2009). Analysis of different routes of administration of heterologous 5-azacytidine-treated mesenchymal stem cells in a porcine model of myocardial infarction. Transplant Proc 41: 2273-2275.

MURRY CE, KELLER G (2008). Differentiation of embryonic stem cells to clinically relevant populations: lessons from embryonic development. Cell 132: 661-680.

MURRY CE, SOONPAA MH, REINECKE H, NAKAJIMA H, NAKAJIMA HO, RUBART M, PASUMARTHI KB, VIRAG JI, BARTELMEZ SH, POPPA V, BRADFORD G, DOWELL JD, WILLIAMS DA, FIELD LJ (2004). Haematopoietic stem cells do not transdifferentiate into cardiac myocytes in myocardial infarcts. Nature 428: 664-668.

NELSON TJ, MARTINEZ-FERNANDEZ A, YAMADA S, PEREZ-TERZIC C, IKEDA $Y, T E R Z I C A$ (2009). Repair of acute myocardial infarction by human stemness factors induced pluripotent stem cells. Circulation 120: 408-416.

NUSSBAUM J, MINAMI E, LAFLAMME MA, VIRAG JA, WARE CB, MASINO A, MUSKHELI V, PABON L, REINECKE H, MURRY CE (2007). Transplantation of undifferentiated murine embryonic stem cells in the heart: teratoma formation and immune response. FASEB $J$ 21: 1345-1357.

OH H, BRADFUTE SB, GALLARDO TD, NAKAMURA T, GAUSSIN V, MISHINA Y, POCIUS J, MICHAEL LH, BEHRINGER RR, GARRY DJ, ENTMAN ML, SCHNEIDER MD (2003). Cardiac progenitor cells from adult myocardium: homing, differentiation, and fusion after infarction. Proc Natl Acad Sci USA 100: 12313-12318.

OKITA K, NAKAGAWA M, HYENJONG H, ICHISAKA T, YAMANAKA S (2008), Generation of mouse induced pluripotent stem cells without viral vectors. Science 322: 949-953.

ORLIC D, KAJSTURA J, CHIMENTI S, JAKONIUK I, ANDERSON SM, LI B, PICKEL J, MCKAY R, NADAL-GINARD B, BODINE DM, LERI A, ANVERSA P (2001). Bone marrow cells regenerate infarcted myocardium. Nature 410: 701705.

PASSIER R, VAN LAAKE LW, MUMMERY CL (2008). Stem-cell-based therapy and lessons from the heart. Nature 453: 322-329.

PERIN EC, LOPEZ J (2006). Methods of stem cell delivery in cardiac diseases. Nat Clin Pract Cardiovasc Med 3 Suppl 1: S110-113.

PITTENGER MF, MARTIN BJ (2004). Mesenchymal stem cells and their potential as cardiac therapeutics. Circ Res 95: 9-20.
PLANAT-BENARD V, MENARD C, ANDRE M, PUCEAT M, PEREZ A, GARCIAVERDUGO JM, PENICAUD L, CASTEILLA L (2004). Spontaneous cardiomyocyte differentiation from adipose tissue stroma cells. Circ Res 94: 223-229.

PLANAT-BENARD V, SILVESTRE JS, COUSIN B, ANDRE M, NIBBELINK M, TAMARAT R, CLERGUE M, MANNEVILLE C, SAILLAN-BARREAU C, DURIEZ M, TEDGUI A, LEVY B, PENICAUD L, CASTEILLA L (2004). Plasticity of human adipose lineage cells toward endothelial cells: physiological and therapeutic perspectives. Circulation 109: 656-663.

PONS J, HUANG Y, ARAKAWA-HOYT J, WASHKO D, TAKAGAWA J, YE J, GROSSMAN W, SU H (2008). VEGF improves survival of mesenchymal stem cells in infarcted hearts. Biochem Biophys Res Commun 376: 419-422.

PONS J, HUANG Y, TAKAGAWA J, ARAKAWA-HOYT J, YE J, GROSSMAN W, KAN YW, SU H (2009). Combining angiogenic gene and stem cell therapies for myocardial infarction. J Gene Med 11: 743-753.

PRICE MJ, CHOU CC, FRANTZEN M, MIYAMOTO T, KAR S, LEE S, SHAH PK, MARTIN BJ, LILL M, FORRESTER JS, CHEN PS, MAKKAR RR (2006). Intravenous mesenchymal stem cell therapy early after reperfused acute myocardial infarction improves left ventricular function and alters electrophysiologic properties. Int J Cardiol 111: 231-239.

REFFELMANN T, KONEMANN S, KLONER RA (2009). Promise of blood- and bone marrow-derived stem cell transplantation for functional cardiac repair: putting it in perspective with existing therapy. J Am Coll Cardiol 53: 305-308.

SCHACHINGER V, AICHER A, DOBERT N, ROVER R, DIENER J, FICHTLSCHERER S, ASSMUS B, SEEGER FH, MENZEL C, BRENNER W, DIMMELER S, ZEIHER AM (2008). Pilot trial on determinants of progenitor cell recruitment to the infarcted human myocardium. Circulation 118: 1425-1432.

SCHACHINGER V, ERBS S, ELSASSER A, HABERBOSCH W, HAMBRECHT R, HOLSCHERMANN H, YU J, CORTI R, MATHEY DG, HAMM CW, SUSELBECK T, ASSMUS B, TONN T, DIMMELER S, ZEIHER AM (2006). Intracoronary bone marrow-derived progenitor cells in acute myocardial infarction. $N$ Engl $J$ Med 355: 1210-1221.

SCHACHINGER V, ERBS S, ELSASSER A, HABERBOSCH W, HAMBRECHT R, HOLSCHERMANN H, YU J, CORTI R, MATHEY DG, HAMM CW, SUSELBECK T, WERNER N, HAASE J, NEUZNER J, GERMING A, MARK B, ASSMUS B, TONN T, DIMMELER S, ZEIHER AM (2006). Improved clinical outcome after intracoronary administration of bone-marrow-derived progenitor cells in acute myocardial infarction: final 1-year results of the REPAIR-AMI trial. Eur Heart $J$ 27: 2775-2783.

SCHULERI KH, AMADO LC, BOYLE AJ, CENTOLA M, SALIARIS AP, GUTMAN MR, HATZISTERGOS KE, OSKOUEI BN, ZIMMET JM, YOUNG RG, HELDMAN AW, LARDO AC, HARE JM (2008). Early improvement in cardiac tissue perfusion due to mesenchymal stem cells. Am J Physiol Heart Circ Physiol 294: H2002-2011.

SEGERS VF, LEE RT (2008). Stem-cell therapy for cardiac disease. Nature 451 : 937-942.

SHAO H, TAN Y, ETON D, YANG Z, UBERTI MG, LI S, SCHULICK A, YU H (2008). Statin and stromal cell-derived factor-1 additively promote angiogenesis by enhancement of progenitor cells incorporation into new vessels. Stem Cells 26 : 1376-1384.

SHERMAN W, MARTENS TP, VILES-GONZALEZ JF, SIMINIAK T (2006). Catheter-based delivery of cells to the heart. Nat Clin Pract Cardiovasc Med.3 Suppl 1: S57-64.

SIEVEKING DP, BUCKLE A, CELERMAJERDS, NG MK (2008). Strikingly different angiogenic properties of endothelial progenitor cell subpopulations: insights from a novel human angiogenesis assay. J Am Coll Cardiol 51: 660-668.

SMITH AG (2001). Embryo-derived stem cells: of mice and men. Annu Rev Cell Dev Biol 17: 435-462.

SMITH RR, BARILE L, MESSINA E, MARBAN E (2008). Stem cells in the heart: what's the buzz all about?-Part 1: preclinical considerations. Heart Rhythm 5 : 749-757.

SMITS PC, VAN GEUNS RJ, POLDERMANS D, BOUNTIOUKOS M, ONDERWATER EE, LEE CH, MAAT AP, SERRUYS PW (2003). Catheterbased intramyocardial injection of autologous skeletal myoblasts as a primary treatment of ischemic heart failure: clinical experience with six-month follow-up. J Am Coll Cardiol 42: 2063-2069.

SORRENTINO SA, BAHLMANN FH, BESLER C, MULLER M, SCHULZ S, 
KIRCHHOFF N, DOERRIES C, HORVATH T, LIMBOURG A, LIMBOURG F, FLISER D, HALLER H, DREXLER H, LANDMESSER U (2007). Oxidant stress impairs in vivo reendothelialization capacity of endothelial progenitor cells from patients with type 2 diabetes mellitus: restoration by the peroxisome proliferatoractivated receptor-gamma agonist rosiglitazone. Circulation.116:163-173.

SPYRIDOPOULOS I, HAENDELER J, URBICH C, BRUMMENDORF TH, OH H, SCHNEIDER MD, ZEIHER AM, DIMMELER S (2004). Statins enhance migratory capacity by upregulation of the telomere repeat-binding factor TRF2 in endothelial progenitor cells. Circulation.110:3136-3142.

STRAUER BE, BREHM M, ZEUS T, KOSTERING M, HERNANDEZ A, SORG RV, KOGLER G, WERNET P (2002). Repair of infarcted myocardium by autologous intracoronary mononuclear bone marrow cell transplantation in humans. Circulation. 106:1913-1918.

SUAREZ Y, FERNANDEZ-HERNANDO C, POBER JS, SESSA WC (2007). Dice dependent microRNAs regulate gene expression and functions in human endothelial cells. Circ Res.100:1164-1173.

SUAREZ Y, SESSA WC (2009). MicroRNAs as novel regulators of angiogenesis. Circ Res 104: 442-454.

TAKAHASHI K, TANABE K, OHNUKI M, NARITA M, ICHISAKA T, TOMODA K, YAMANAKA $S$ (2007). Induction of pluripotent stem cells from adult human fibroblasts by defined factors. Cell 131: 861-872.

TANG J, WANG J, YANG J, KONG X, ZHENG F, GUO L, ZHANG L, HUANG Y (2009). Mesenchymal stem cells over-expressing SDF-1 promote angiogenesis and improve heart function in experimental myocardial infarction in rats. Eur $J$ Cardiothorac Surg 36: 644-650.

TANG YL, TANG Y, ZHANG YC, QIAN K, SHEN L, PHILLIPS MI (2005). Improved graft mesenchymal stem cell survival in ischemic heart with a hypoxia-regulated heme oxygenase-1 vector. J Am Coll Cardiol 46: 1339-1350.

TEMPLIN C, KOTLARZ D, MARQUART F, FAULHABER J, BRENDECKE $\mathrm{V}$, SCHAEFER A, TSIKAS D, BONDA T, HILFIKER-KLEINER D, OHL L, NAIM HY, FOERSTER R, DREXLER H, LIMBOURG FP (2006). Transcoronary delivery of bone marrow cells to the infarcted murine myocardium: feasibility, cellular kinetics, and improvement in cardiac function. Basic Res Cardiol 101: 301-310.

TEMPLIN C, KOTLARZ D, RATHINAM C, RUDOLPH C, SCHATZLEIN S, RAMIREDDY K, RUDOLPH KL, SCHLEGELBERGER B, KLEIN C, DREXLER $H$ (2008). Establishment of immortalized multipotent hematopoietic progenitor cell lines by retroviral-mediated gene transfer of beta-catenin. Exp Hemato/36: 204-215.

TEMPLIN C, KOTLARZ D, FAULHABER J, SCHNABEL S, GROTE K, SALGUERO G, LUCHTEFELD M, HILLER KH, JAKOB P, NAIM HY, SCHIEFFER B, HILFIKER-KLEINERD, LANDMESSERU, LIMBOURG FP, DREXLERH (2008). Ex vivo expanded hematopoietic progenitor cells improve cardiac function after myocardial infarction: role of beta-catenin transduction and cell dose. J Mol Cell Cardiol 45: 394-403.

TEMPLIN C, LUESCHER TF, LANDMESSER U (2010). Stem and progenitor cellbased therapy approaches: current developments on treatment of acute myocardial infarction and chronic ischemic cardiomyopathy. [Article in German]. Herz. 35: 445-456.

TENDERA M, WOJAKOWSKI W, RUZYLLO W, CHOJNOWSKA L, KEPKA C, TRACZ W, MUSIALEK P, PIWOWARSKA W, NESSLER J, BUSZMAN P, GRAJEK S, BREBOROWICZ P, MAJKA M, RATAJCZAK MZ (2009). Intracoronary infusion of bone marrow-derived selected CD34+CXCR4+ cells and non-selected mononuclear cells in patients with acute STEMI and reduced left ventricular ejection fraction: results of randomized, multicentre Myocardial Regeneration by Intracoronary Infusion of Selected Population of Stem Cells in Acute Myocardial Infarction (REGENT) Trial. Eur Heart J 30: 1313-1321.

THOMPSON CA, NASSERI BA, MAKOWER J, HOUSER S, MCGARRY M, LAMSON T, POMERANTSEVA I, CHANG JY, GOLD HK, VACANTI JP, OESTERLE SN (2003). Percutaneous transvenous cellular cardiomyoplasty. A novel nonsurgical approach for myocardial cell transplantation. J Am Coll Cardiol 41: 1964-1971.
TOMA C, PITTENGER MF, CAHILL KS, BYRNE BJ, KESSLER PD (2002). Human mesenchymal stem cells differentiate to a cardiomyocyte phenotype in the adult murine heart. Circulation 105: 93-98.

TOMITA S, LI RK, WEISEL RD, MICKLE DA, KIM EJ, SAKAI T, JIA ZQ (1999). Autologous transplantation of bone marrow cells improves damaged heart function. Circulation 100: 11247-256.

TOSSIOSP, KRAUSGRILL B, SCHMIDT M, FISCHERT, HALBACH M, FRIES JW, FAHNENSTICH S, FROMMOLT P, HEPPELMANN I, SCHMIDT A SCHOMACKER K, FISCHER JH, BLOCH W, MEHLHORN U, SCHWINGER $\mathrm{RH}$, MULLER-EHMSEN J (2008). Role of balloon occlusion for mononuclear bone marrow cell deposition after intracoronary injection in pigs with reperfused myocardial infarction. Eur Heart J 29: 1911-1921.

UEMURA R, XU M, AHMAD N, ASHRAF M (2006). Bone marrow stem cells prevent left ventricular remodeling of ischemic heart through paracrine signaling. Circ Res 98: 1414-1421.

URBICH C, AICHER A, HEESCHEN C, DERNBACH E, HOFMANN WK, ZEIHER AM, DIMMELER S (2005). Soluble factors released by endothelial progenitor cells promote migration of endothelial cells and cardiac resident progenitor cells. J Mol Cell Cardiol 39: 733-742.

URBICH C, DIMMELER S (2004). Endothelial progenitor cells: characterization and role in vascular biology. Circ Res 95: 343-353.

VAN LAAKE LW, PASSIER R, DOEVENDANS PA, MUMMERY CL (2008). Human embryonic stem cell-derived cardiomyocytes and cardiac repair in rodents. Circ Res 102: 1008-1010.

VAN ROOIJ E, MARSHALL WS, OLSON EN (2008). Toward microRNA-based therapeutics for heart disease: the sense in antisense. Circ Res 103: 919-928.

VASA M, FICHTLSCHERER S, AICHER A, ADLER K, URBICH C, MARTIN H, ZEIHER AM, DIMMELER S (2001). Number and migratory activity of circulating endothelial progenitor cells inversely correlate with risk factors for coronary artery disease. Circ Res 89: E1-7.

VULLIET PR, GREELEY M, HALLORAN SM, MACDONALD KA, KITTLESON MD (2004). Intra-coronary arterial injection of mesenchymal stromal cells and microinfarction in dogs. Lancet 363: 783-784.

WOLLERT KC, MEYER GP, LOTZ J, RINGES-LICHTENBERG S, LIPPOLT P, BREIDENBACH C, FICHTNER S, KORTE T, HORNIG B, MESSINGER D, ARSENIEV L, HERTENSTEIN B, GANSER A, DREXLER H (2004). Intracoronary autologous bone-marrow cell transfer after myocardial infarction: the BOOST randomised controlled clinical trial. Lancet 364: 141-148.

YANG J, ZHOU W, ZHENG W, MA Y, LIN L, TANG T, LIUJ, YU J, ZHOU X, HU J(2007). Effects of myocardial transplantation of marrow mesenchymal stem cells transfected with vascular endothelial growth factor for the improvement of heart function and angiogenesis after myocardial infarction. Cardiology 107: 17-29.

YU J, VODYANIK MA, SMUGA-OTTO K, ANTOSIEWICZ-BOURGET J, FRANE JL, TIAN S, NIE J, JONSDOTTIR GA, RUOTTI V, STEWART R, SLUKVIN, II, THOMSON JA (2007). Induced pluripotent stem cell lines derived from human somatic cells. Science 318: 1917-1920.

ZARUBA MM, THEISS HD, VALLASTER M, MEHL U, BRUNNER S, DAVID R, FISCHER R, KRIEG L, HIRSCH E, HUBER B, NATHAN P, ISRAEL L, IMHOF A, HERBACH N, ASSMANN G, WANKE R, MUELLER-HOECKER J, STEINBECK G, FRANZ WM (2009). Synergy between CD26/DPP-IV inhibition and G-CSF improves cardiac function after acute myocardial infarction. Cell Stem Cell 4: 313-323.

ZHANG J, WILSON GF, SOERENS AG, KOONCE CH, YU J, PALECEK SP, THOMSON JA, KAMP TJ (2009). Functional cardiomyocytes derived from human induced pluripotent stem cells. Circ Res 104: e30-41.

ZHAO T, ZHANG D, MILLARD RW, ASHRAF M, WANG Y (2009). Stem cell homing and angiomyogenesis in transplanted hearts are enhanced by combined intramyocardial SDF-1alpha delivery and endogenous cytokine signaling. $\mathrm{Am} J$ Physiol Heart Circ Physiol 296: H976-986. 


\section{Further Related Reading, published previously in the Int. J. Dev. Biol.}

Insulin-like growth factor-2 regulates early neural and cardiovascular system development in zebrafish embryos

Lori Hartnett, Catherine Glynn, Catherine M. Nolan, Maura Grealy and Lucy Byrnes

Int. J. Dev. Biol. (2010) 54: 573-583

The seminal work of Werner Risau in the study of the development of the vascular system

Domenico Ribatti

Int. J. Dev. Biol. (2010) 54: 567-572

Estrogen regulation of placental angiogenesis and fetal ovarian development during primate pregnancy

Eugene D. Albrecht and Gerald J. Pepe

Int. J. Dev. Biol. (2010) 54: 397-407

Uteroplacental vascular development and placental function: an update

Lawrence P. Reynolds, Pawel P. Borowicz, Joel S. Caton, Kimberly A. Vonnahme, Justin S. Luther, David S. Buchanan, Shireen A. Hafez, Anna T. Grazul-

Bilska and Dale A. Redmer

Int. J. Dev. Biol. (2010) 54: 355-365

Critical growth factors and signalling pathways controlling human trophoblast invasion

Martin Knöfler

Int. J. Dev. Biol. (2010) 54: 269-280

Over-expression of thymosin beta4 promotes abnormal tooth development and stimulation of hair growth

Hee-Jae Cha, Deborah Philp, Soo-Hyun Lee, Hye-Sung Moon, Hynda K. Kleinman and Takashi Nakamura

Int. J. Dev. Biol. (2010) 54: 135-140

The contribution of Roberto Montesano to the study of interactions between epithelial sheets and the surrounding extracellular matrix Domenico Ribatti

Int. J. Dev. Biol. (2010) 54: 1-6

A critical role for myoglobin in zebrafish development

Danielle H. Vlecken, Janwillem Testerink, Elisabeth B. Ott, Philippe A. Sakalis, Richard T. Jaspers and Christoph P. Bagowski

Int. J. Dev. Biol. (2009) 53: 517-524

Embryonic development of the proepicardium and coronary vessels

Anna Ratajska, Elzbieta Czarnowska and Bogdan Ciszek

Int. J. Dev. Biol. (2008) 52: 229-236

Vasculogenesis and angiogenesis in the mouse embryo studied using quail/mouse chimeras

Michel Pudliszewski and Luc Pardanaud

Int. J. Dev. Biol. (2005) 49: 355-361

Parallels in invasion and angiogenesis provide pivotal points for therapeutic intervention

Suzanne A. Eccles

Int. J. Dev. Biol. (2004) 48: 583-598

5 yr ISI Impact Factor $(2009)=3.253$
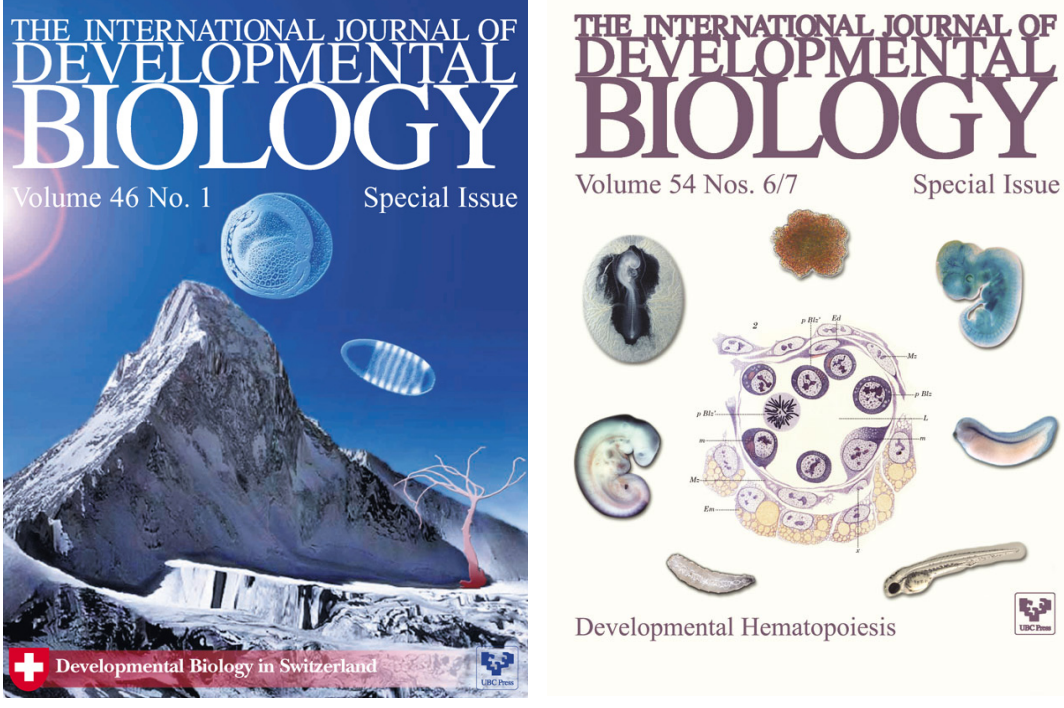

Volume 54 Nos. $6 / 7$
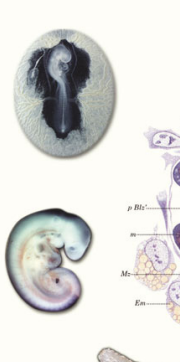

Developmental Hematopoiesi
Special Issue
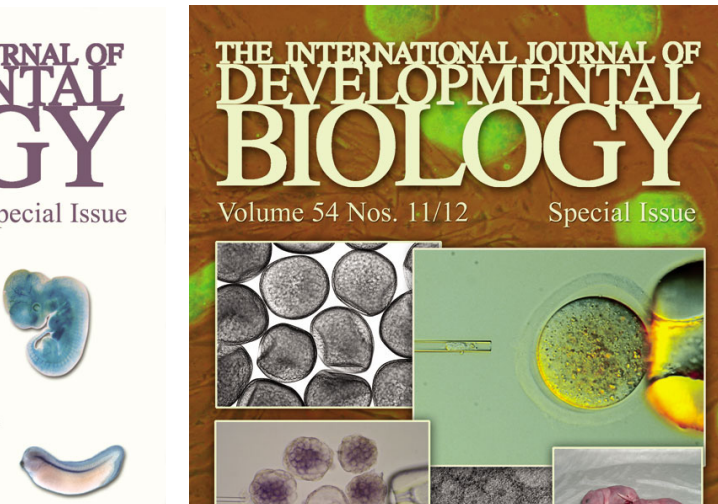

Volume 54 Nos. $11 / 12$

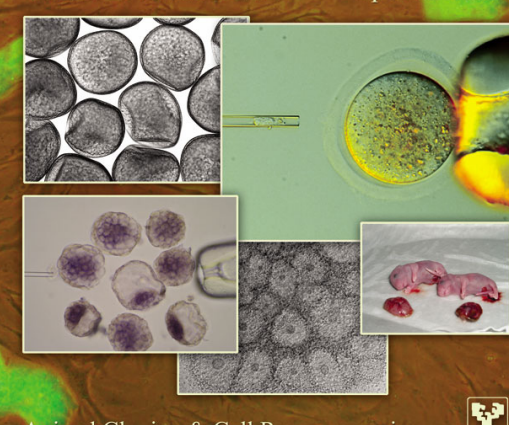

Animal Cloning \& Cell Reprogramming 